\title{
Effects of Management Practices and Environmental Factors on Largemouth Bass Abundance in Illinois Inland Lakes
}

\author{
Ralf Riedel1 $^{1 *}$, Peter Bayley², Douglas Austen ${ }^{3}$ \\ ${ }^{1}$ Illinois Natural History Survey, Urbana, IL, USA \\ ${ }^{2}$ Department of Fisheries and Wildlife, Oregon State University, Corvalis, OR, USA \\ ${ }^{3}$ Illinois Department of Natural Resources, Springfield, IL, USA \\ Email: ^ralf.riedel@usm.edu,piscesb@runbox.com,dausten@fisheries.org
}

How to cite this paper: Riedel, R., Bayley, P. and Austen, D. (2017) Effects of Management Practices and Environmental Factors on Largemouth Bass Abundance in Illinois Inland Lakes. Natural Resources, 8, 234-253. https://doi.org/10.4236/nr.2017.83013

Received: February 18, 2017

Accepted: March 28, 2017

Published: March 31, 2017

Copyright $\odot 2017$ by authors and Scientific Research Publishing Inc. This work is licensed under the Creative Commons Attribution International License (CC BY 4.0).

http://creativecommons.org/licenses/by/4.0/

(c) (i) Open Access

\begin{abstract}
An understanding of the relative importance of natural factors and management practices affecting largemouth bass (Micropterus salmoides) abundance is key for enhanced angling. Standardized fish surveys, management practices, and environmental data were available from 42 man-made, inland lakes between 1960 and 1991. Management practices tested were largemouth bass stocking, lake rehabilitation, water level manipulation, aquatic vegetation controls, small fish removal, and changes in length limits of harvestable fish. Environmental factors not controlled by management were spring water influx, growing and cooling degree days, and snow depth. Lake rehabilitation (complete drainage and reflooding), changes in length limits, and aquatic vegetation controls were the only significant factors affecting largemouth bass abundance. The largest effects were due to lake rehabilitation, which increased next-year young largemouth bass numbers by $566 \%$ on average, and more restrictive limits on harvestable size, with an increase of up to $440 \%$ in adult numbers.
\end{abstract}

\section{Keywords}

Largemouth Bass, Management, Environment, Length-Limits, Habitat, Electrofishing

\section{Introduction}

The need for incorporating environmental processes into fisheries management is being increasingly recognized as we gain insight into the complexities and interrelations of ecosystems. The relative influence of environmental factors and management practices on fish abundance may allow us to better estimate the 
importance of natural phenomena when devising management plans. Environmental conditions may interact with management practices [1] and produce unexpected outcomes. Environmental effects outside the control of managers may overwhelm the effects of fisheries management [2], making fish abundance appear to fluctuate unpredictably and irrespective of management interventions. Environmental factors are often ignored because of their unpredictability. If, however, uncontrolled environmental effects are major determinants of fish abundance, management effectiveness may decrease, potentially leading to failure. In this paper, we consider traditional fisheries management practices that affect the fishing process as well as practices that affect the fish environment, in addition to environmental effects that cannot be controlled by the fisheries manager. If we can better understand the effects of management and environmental factors on fish, estimating the cost-effectiveness of management scenarios may be attainable.

Largemouth bass (Micropterus salmoides) is one of the most important and widespread species targeted by management of inland sport fishing [3] [4]. Although quality angling is a subjective concept [5], it is generally associated with some combination of fish size and abundance [6], which in turn is determined by a combination of management practices and environmental variation.

Lake drawdowns have been shown effective for increasing centrarchid growth rates [7] [8], abundance [9] [10], and in controlling undesired species of fish [11]. Among management practices, size regulations are the most widespread for managing fish [12] [13]. Fishing regulations have been effective as tools to restructure population size [14] [15] [16]. Fishing regulations have also been shown to produce variable results on fish. Van Horn et al. [17] investigated a 45 $\mathrm{cm}$ minimum length limit on largemouth bass in four North Carolina reservoirs. The proportion of fish larger than $300 \mathrm{~mm}$ increased in two reservoirs and remained unchanged in the other two. Novinger [18] reported inconsistent results of a $375 \mathrm{~mm}$ minimum length on largemouth bass at Table Rock Lake, Missouri. Variation in year-class strength due to environmental factors was the attributed cause of the inconsistencies. Management practices have also been shown to be ineffective ([19] for fishing regulations; [20] [21] for fish stocking), possibly due to large variations in environmental factors.

Largemouth bass abundance has been correlated with type of nesting substrate [22]. Nests located in recently flooded areas potentially increase young largemouth bass abundance [23]. Temperature has been positively correlated with egg survival and young growth [22]. Temperature may also indirectly affect largemouth bass survival during the winter. Low temperatures may decrease largemouth bass tolerance for low dissolved oxygen [24] [25].

The effectiveness of management regulations may, thus, not only be dependent on the type of practice and its intensity, but also on the interplay between the management and the environmental components. We investigated in this paper the efficacy of current largemouth bass management in light of natural environmental variation in an attempt to shed some light into the degree of con- 
trol inland fisheries management has in determining fish abundance.

\section{Methods}

\subsection{Data Sources}

Data to derive the predictors representing the environmental and management components (Table 1) were gathered from forty-two man-made Illinois lakes (Figure 1; Table 2) with fisheries management information and fish samples between 1960 and 1991.

\subsubsection{Environmental Variables}

The effects of precipitation, growing degree days, cooling degree days, and lake morphometry were used as proxies for assessing the effects of the environment on largemouth bass. Climatic information was obtained from the US Midwest Climate Center weather stations, using data from the closest station located within the same catchment basin of each lake. If data from the closest weather station were unavailable, the next station closest to the lake was chosen, as long

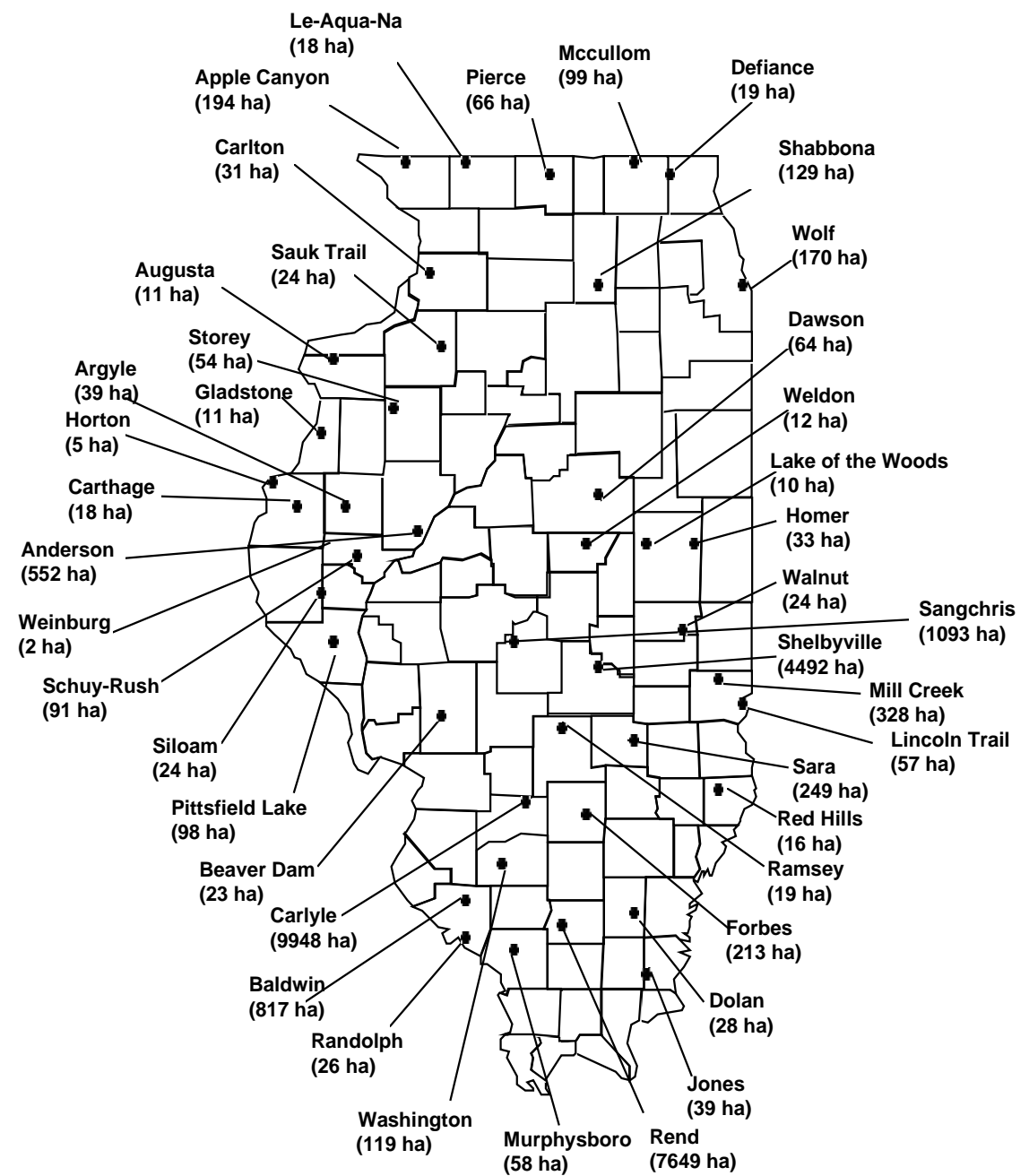

Figure 1. Names and surface area for the 42 Illinois (USA) inland lakes used to investigate environmental and anthropogenic effects on largemouth bass abundance. 
Table 1. Summary statistics and summary diagnostics for predictors for the natural environmental and management components. SFI- [(precipitation $*$ watershed area $) *(1+$ percent uncovered land)]/(lake volume*volume development index); GDD—Growing degree days; CDD—Cooling degree days; SND—Snow depth.

\begin{tabular}{|c|c|c|c|c|}
\hline Predictors & Mean & $\begin{array}{l}\text { Standard } \\
\text { Deviation }\end{array}$ & Range & $\begin{array}{l}\text { Delay Lags in } \\
\text { Years Tested }\end{array}$ \\
\hline \multicolumn{5}{|l|}{ Natural Environmental } \\
\hline -SFI & 0.07 & 0.20 & $0-1.8$ & 0 and 1 \\
\hline$-\mathrm{GDD}\left({ }^{\circ} \mathrm{C}\right)$ & 3423 & 451 & $1990-4670$ & 0 and 1 \\
\hline$-\mathrm{CDD}\left({ }^{\circ} \mathrm{C}\right)$ & 616 & 324 & $20-1830$ & 0 and 1 \\
\hline$-\mathrm{SND}(\mathrm{mm})$ & 37.2 & 43 & $1-440$ & 0 and 1 \\
\hline \multicolumn{5}{|l|}{ Management Practices } \\
\hline \multicolumn{5}{|l|}{ Continuous variables: } \\
\hline $\begin{array}{l}\text {-Stocking of largemouth bass } \\
\text { (numbers fish/ha) }\end{array}$ & 7.6 & 59 & $0-1110$ & 1 \\
\hline -Water level reduction $(\mathrm{cm})$ & 7.8 & 39 & $0-460$ & 0 and 1 \\
\hline \multicolumn{5}{|l|}{ Dichotomous variables: } \\
\hline -Fish removal practice & & & $0-1$ & 0 and 1 \\
\hline -Aquatic vegetation control & & & $0-1$ & 0 and 1 \\
\hline -Lake rehabilitation & & & $0-1$ & 1 and 2 \\
\hline $\begin{array}{l}-350 \mathrm{~mm} \text { largemouth bass minimum } \\
\text { length limit* }\end{array}$ & & & $0-1$ & 0 \\
\hline $\begin{array}{l}-375 \mathrm{~mm} \text { largemouth bass minimum } \\
\text { length limit }{ }^{*}\end{array}$ & & & $0-1$ & 0 \\
\hline $\begin{array}{l}\text {-300 - } 375 \mathrm{~mm} \text { largemouth bass slot } \\
\text { length limit }\end{array}$ & & & $0-1$ & 0 \\
\hline $\begin{array}{l}\text { - Tested against the statewide } \\
\text { minimum length of } 300 \mathrm{~mm} \text {. }\end{array}$ & & & & \\
\hline
\end{tabular}

as the station was located in the same catchment basin. Lake morphometric data comprised of lake watershed area, lake volume, lake catchment area percent of land use practice, and lake volume development index. Morphometric data were obtained from [26].

Precipitation during May and June was chosen as a surrogate variable for hydrologic factors influencing age-0 largemouth bass survival through the spawning season. The potential effects of precipitation taking into account the drainage area and land use were investigated by defining a spring flooding index (SFI), representing the amount of water and sediment carried into the lake for given levels of precipitation. The flooding index was defined according to Riedel [27] as

$$
S F I=(P T * W A / L V) *(1+L P / V D),
$$

where $P T$ is the amount of precipitation $(\mathrm{cm}), W A$ is the watershed area (ha), $L V$ is the lake volume $\left(1000 \mathrm{~m}^{3}\right), L P$ is the land use practice index (see below), and $V D$ is the lake volume development index [28]. Variable $L P$ was the pro- 
Table 2. Characteristics of lakes used to determine the effects of natural and fisheries management practices on the abundance of largemouth bass. STO-stocking, VGaquatic vegetation control, WM- water level manipulation, $\mathrm{RH}$-lake rehabilitation, $\mathrm{R} 1$ imposition of a $350 \mathrm{~mm}$ minimum length limit, R2-imposition of a $375 \mathrm{~mm}$ minimum length limit, RS-imposition of a 350 - $375 \mathrm{~mm}$ slot length limit, -, unavailable data.

\begin{tabular}{|c|c|c|c|c|}
\hline Name & $\begin{array}{l}\text { Management practices } \\
\text { tested }\end{array}$ & $\begin{array}{l}\text { Surface } \\
\text { area (ha) }\end{array}$ & $\begin{array}{l}\text { Mean } \\
\text { depth } \\
(\mathrm{m})\end{array}$ & $\begin{array}{c}\text { Latitude } \\
\left({ }^{\circ} \mathrm{N}\right) / \text { Longitude } \\
\left({ }^{\circ} \mathrm{W}\right)\end{array}$ \\
\hline $\begin{array}{l}\text {-Weinburg-King } \\
\text { Lake } 1\end{array}$ & VG, WM & 2 & - & $4003 / 9050$ \\
\hline -Horton Lake & $\mathrm{RH}, \mathrm{WM}$ & 4 & 3.4 & $4032 / 9123$ \\
\hline -Augusta Lake & VG, WM & 11 & 1.9 & $4115 / 9055$ \\
\hline -Gladstone Lake & RS, RH, RM, ST, WM & 11 & - & $4050 / 9100$ \\
\hline $\begin{array}{l}\text {-Lake of the } \\
\text { Woods }\end{array}$ & R2, RM, ST, WM & 11 & 2.9 & $4012 / 8823$ \\
\hline -Weldon Springs & R2, RM, VG, WM & 12 & 3.5 & $4007 / 8855$ \\
\hline $\begin{array}{l}\text {-Lake } \\
\text { Le-Aqua-Na }\end{array}$ & R1, RH, ST, VG, WM & 17 & 3.2 & 42 25/89 49 \\
\hline -Red Hills & R2, RM, RH, VG, WM & 17 & 2.2 & $3844 / 8750$ \\
\hline -Carthage Lake & RM, RH, WM & 18 & 3.4 & $4026 / 9109$ \\
\hline -Defiance Lake & R1, RM, WM & 19 & 2.9 & $4219 / 8813$ \\
\hline -Sauk Trail & R1, ST, VG, WM & 21 & 2.3 & $4120 / 8953$ \\
\hline $\begin{array}{l}\text {-Beaver Dam } \\
\text { Lake }\end{array}$ & R2, RS, RM, ST, VG & 22 & 1.9 & $3912 / 8958$ \\
\hline -Ramsey Lake & R1, RM, RH, ST, VG, WM & 22 & 2.5 & $3910 / 8908$ \\
\hline $\begin{array}{l}\text {-Walnut Point } \\
\text { Lake }\end{array}$ & R1, RM, RH, VG, WM & 22 & 3.8 & $3940 / 8802$ \\
\hline -Siloam Springs & RS, RM, RH, ST, VG, WM & 24 & 5.2 & $3952 / 9056$ \\
\hline -Dolan State Lake & R1, RM, VG, WM & 29 & 1.9 & $3803 / 8824$ \\
\hline -Lake Carlton & $\mathrm{R} 1, \mathrm{ST}, \mathrm{VG}$ & 29 & 3.4 & $4151 / 8958$ \\
\hline -Argyle Lake & RS, RH, RM, VG, WM & 33 & 4.9 & $4027 / 9047$ \\
\hline -Homer Lake & $\mathrm{R} 1, \mathrm{RM}$ & 33 & 2.5 & $4003 / 8759$ \\
\hline $\begin{array}{l}\text {-Randolph Co. } \\
\text { Lake }\end{array}$ & R1, RM, ST, VG, WM & 33 & 4.8 & $3758 / 8945$ \\
\hline -Jones State Lake & R1, RM, VG, WM & 40 & 3.8 & $3741 / 8823$ \\
\hline -Lake Storey & RS, RM, RH, VG, WM & 55 & - & $4055 / 9002$ \\
\hline $\begin{array}{l}\text {-Lincoln Trail } \\
\text { Lake }\end{array}$ & RM, RH, ST, VG, WM & 57 & 4.8 & $3920 / 8743$ \\
\hline $\begin{array}{l}\text {-Lake Murphys- } \\
\text { boro }\end{array}$ & R1, RM, RH, ST, VG, WM & 58 & 4.2 & $3746 / 8923$ \\
\hline -Pierce Lake & $\mathrm{R} 1, \mathrm{RM}$ & 61 & 3.4 & 42 20/88 59 \\
\hline -Dawson Lake & RS, RM, RH, ST, VG & 62 & 3.1 & $4024 / 8843$ \\
\hline -Pittsfield Lake & RM, ST, WM & 87 & 3.7 & $3938 / 9045$ \\
\hline -McCullom Lake & R2, RH, ST, WM & 102 & 1.2 & $4221 / 8817$ \\
\hline -Schuy-Rush Lake & ST, WM & 102 & 3.8 & $4003 / 9033$ \\
\hline
\end{tabular}




\begin{tabular}{lcccc} 
Continued & & & & \\
\hline $\begin{array}{l}\text {-Washington Co. } \\
\text { Lake }\end{array}$ & R1, RM, RH, ST, VG, WM & 126 & 5.6 & $3816 / 8922$ \\
-Shabbona Lake & RM, VG, ST, R1 & 127 & 4.7 & $4144 / 8851$ \\
-Wolf Lake & R1, RH, RM, ST & 158 & 1.8 & $4140 / 8732$ \\
-Apple Canyon & RM, ST, WM & 200 & - & $4225 / 9002$ \\
Lake & R1, RM, ST, WM & 226 & 4.6 & $3843 / 8845$ \\
-Forbes Lake & R2 & 256 & 5.8 & $3907 / 8837$ \\
-Lake Sara & RS & 305 & 6.6 & $3924 / 8747$ \\
-Mill Creek Lake & WM & 568 & - & $4000 / 9052$ \\
-Anderson Lake & RM & 817 & 2.4 & $3812 / 8952$ \\
-Baldwin Lake & R2, ST, WM & 967 & 3.8 & $3939 / 8929$ \\
-Lake Sangchris & R1, ST & 4,621 & - & $3927 / 8853$ \\
-Lake Shelbyville & R1, ST & 7,870 & - & $3755 / 8910$ \\
-Rend Lake & R1, ST & 10,234 & - & $3840 / 8858$ \\
-Carlyle Lake & & & & \\
\hline
\end{tabular}

portion of catchment area that was uncovered land (barren, agricultural, and urban). One was added to the $L P / V D$ ratio to avoid zero values in the SFI for watershed with only vegetative cover. $V D$ was a denominator because smaller $V D$ values may lead to increased flooded areas for the same value of precipitation. Similarly, $L P$ was a numerator because uncovered land may lead to an increase in water turbidity. The lake volume and lake volume development indices were used to account for differences in the amount of flooded land among lakes with similar precipitation regimes.

Growing degree-days (GDD) (Table 1) represented the potential for largemouth bass growth. Only the months between April and October were considered for GDD estimation because largemouth bass in Illinois grow little or cease to grow during the other months of the year [29] [30]. Because largemouth bass growth ceases at temperatures below approximately $10^{\circ} \mathrm{C}$ [29] [30] [31], and that was the base temperature chosen for calculating growing degree days (Table 1).

Cooling degree days and monthly average snow depth for December through March were used as proxies for the effects of low dissolved oxygen on largemouth bass due to ice and snow cover (Table 1). The base temperature for cooling degree days was $0^{\circ} \mathrm{C}$.

\subsubsection{Management Practices}

The management practices tested were largemouth bass stocking, lake rehabilitation (complete drainage and reflooding), lake water level manipulation, aquatic vegetation controls (surface vegetation potentially causing declines in dissolved oxygen), removals of small fish (potentially overpopulating lakes), and changes in regulations involving largemouth bass length limits. Data on management practices (Table 1) were gathered from archives at the Illinois Department of Natural Resources (IDNR) fisheries district offices. Largemouth bass data collected by IDNR and their management interventions have followed 
standard procedures since the early 1960s, allowing year-to-year comparisons among lakes. Data on fish abundance estimates to derive the response variables were obtained from fall electrofishing sampling records archived at the IDNR district offices and the Fisheries Analysis System database [32]. Length limit regulations for largemouth bass were collected from the Illinois State Library and the Illinois Register. Data pertaining to the predictors and the response variables were obtained only for those lakes with management, fish sampling, and climatic records dating back to 1960 and with at least a yearly electrofishing sampling schedule in the fall. Because year was the observational unit for estimating effects on the response variable, only lakes where a management practice was done were selected to investigate the effects of that practice.

\subsubsection{Choice of Response Variables}

A response variable for adult (adult-fish) and one for first year (age-1) largemouth bass were derived and investigated independently. The age 1 class (fish within the range of 80 and $120 \mathrm{~mm}$ total length; [33]) was used to investigate the effects of practices other than changes in size limit regulations. Typical harvestable ages of largemouth bass in Illinois are age-3 (300 $\mathrm{mm}$ and larger) and older [34] [35], minimizing potential confounding effects between size regulations (potential effects examined on age- 3 fish) and other management practices (potential effects examined on age-1 fish). Adult largemouth bass were chosen to offer a direct measure of the effects of size limit regulations. The adult-fish response variable was derived from largemouth bass $300 \mathrm{~mm}$ and larger. The length boundaries for the age- 1 response variable were estimated using a likelihood-based method for analyzing multiple length data sampled through time (MULTIFAN; [36]), resulting in a lower boundary of $136 \mathrm{~mm} \pm 19.5 \mathrm{~mm}$ and an upper boundary of $195 \mathrm{~mm} \pm 21.3 \mathrm{~mm}$ SD. Numbers of largemouth bass sampled per hour of fall electrofishing were corrected for catchability to provide estimates for inshore fish density that were logarithm transformed to produce the response variable.

Catchability correction factors for fish numbers were calculated from calibration data in [37] [38] to obtain estimates of abundance. Abundance was represented as density of fish in an inshore zone $13 \mathrm{~m}$ wide, the typical distance from shore fished by the boat mounted electrofishing gear. Catchability was estimated with the log-linear relationship

$$
q=\left\{1 /\left[1+e^{\left(3.47+0.184 * L-0.0033 * L^{2}\right)}\right]\right\}^{2},
$$

where $q$ is the catchability and $L$ is the total length of largemouth bass in $\mathrm{cm}$. The average speed of the boat electroshocker as used by fisheries biologist in Illinois is $(0.43 \pm 0.15) \mathrm{SD} \mathrm{m} / \mathrm{s}$ [37] (Bayley and Austen 1987), which corresponds to a $1550-\mathrm{m}$ distance in one hour. Inshore fish density was estimated with the relationship

$$
d=\left\{\left[(\mathrm{CPUE}) * 10^{4}\right] /(q * 1550 \mathrm{~m} * 13 \mathrm{~m})\right\},
$$

where $d$ is numbers of fish/ha and CPUE is numbers fish caught/hour. 


\subsection{Analytical Procedures}

\subsubsection{General Analyses}

Each predictor (management or environmental; Table 1) was treated separately to avoid confounding (Sections 2.4 and 2.5). Predictors for management were dichotomous (coded as 0 or 1 ) or continuous variables. Dichotomous predictors were coded as one for the year they occurred at a lake (treatment years) and zero for years without any management practice (control years). Effects of length limits were tested against the default statewide minimum length of $300 \mathrm{~mm}$. All other management factors were tested against control years, during which none were in force. Predictors for the environmental component were treated jointly during each year for which a response variable was calculated to allow assessment of interactions.

General linear models were used to investigate the effects of the predictors and their first-order interactions on each response variable. The observational unit was year and was either a treatment, when a management practice was conducted, or a control, when no management was conducted. Time lags were used for some predictors because they were hypothesized to have a delayed effect on age-1 largemouth bass abundance. A zero delay (lag 0) was defined when predictors were hypothesized to affect fish abundance during the same year. A one-year delay (lag-1) and a two-year delay (lag-2) were used when predictors were hypothesized to affect fish abundance after one and two years, respectively (Table 1).

Power analysis was conducted according to [39], with $r^{2}=0$ as the null hypothesis. Separate models were tested for each treatment-delay effect under a management practice. The decision on which interaction and main effect terms to retain in the model was based on the change in Residual Sums of Squares (RSS) resulting from the exclusion of each term in the model.

The interaction terms for which the RSS analysis yielded non-significant ( $\mathrm{p}>$ 0.05 ) results were individually excluded from analysis, starting with the term that contributed the least to the overall significance of the model. Main effects were always kept in the model when examining the effects of interactions. The main effects were dropped if not significant and not part of a significant interaction term. Each time an interaction term was dropped, the RSS for each of the remaining predictors was recalculated.

\subsubsection{Analysis on the Age-1 Response Variable}

The age-1 response variable was used to assess the effects of management practices and environmental variables on young largemouth bass. Data were selected for lake-year combinations that had received the treatment (management practice) examined. Potentially confounding observations were those years when management practices other than the one being analyzed coincided with the practice being investigated. Data from confounding years were not used.

Except for lake rehabilitation, the observation of largemouth bass density in the fall corresponded to the year the management practice was conducted (lag 
0 ). For rehabilitation, observations for the environmental predictors were of the year after rehabilitation because restocking of largemouth bass was done the year following that practice to restart the fish population (potential environmental effects on young largemouth bass coincided with the year the fish population was initiated).

\subsubsection{Analysis on the Adult-Fish Response Variable}

The adult-fish response variable was used to investigate the effectiveness of largemouth bass length limits in conjunction with environmental factors. Each length limit predictor was analyzed separately. Data selection and the treatment of potentially confounding years were done as described above. Years with lake rehabilitation were not included in analyses of length limits because rehabilitation involves a total lake drawdown, which may also affect adult size. The predictors and analytical procedures described for age-1 fish were used. A zero-delay lag for the response variable was used for all changes in length limit (Table 1) because harvest potentially produces an immediate effect on adult fish abundance.

\section{Results}

The strongest evidence of management practices affecting the age- 1 response variable was for lake rehabilitation. A decline one year and an increase two years following rehabilitation were observed (Table 3). Similarly, there was evidence that changes from the statewide minimum length limit of $300 \mathrm{~mm}$ to larger minimum length regulations did increase adult largemouth bass abundance. Changes from the statewide minimum length to an exclusive $300-375 \mathrm{~mm}$ slot length regulation produced the highest increase (440 percent) in the absolute abundance of $300 \mathrm{~mm}$ and larger largemouth bass among the length limit regulations tested. The lag -2 rehabilitation practice produced the highest increase (566 percent) in the absolute numbers of age 1 largemouth bass among all management practices tested (Table 4).

Environmental variables not controlled by the manager provided little evidence for affecting the age-1 response variable and no evidence for affecting the adult-fish response variable. A decline in age-1 largemouth bass due to the spring flooding index was evident one year following rehabilitation, indicating a negative effect of rainfall upon lake rehabilitation.

\section{Discussion}

\subsection{Effects of Management Practices}

Results provide support for some management practices by having a desired effect on largemouth bass abundance. The effects of extreme practices (lake rehabilitations) and practices remaining over several years (changes in length limits) were associated with the strongest changes in abundance. Lake rehabilitation produced the highest effects on fish abundance compared with the other management practices tested. An increase in fish abundance following a water level 
Table 3. Results for management effects on the abundance of largemouth bass from electrofishing samples. SFI-(precipitation $*$ watershed area/lake volume $) *(1+$ percent uncovered land/volume development index); GDD—Growing degree days $\left({ }^{\circ} \mathrm{C}\right)$; $\mathrm{CDD} —$ Cooling degree days $\left({ }^{\circ} \mathrm{C}\right)$; SND—Snow depth (millimeters); MAN-Predictor for the management practice. ${ }^{*} \mathrm{p}$-value $<0.05 ;{ }^{*} \mathrm{p}<0.01$; non-significant coefficients are omitted (dashes). $(P T * W A / L V) *(1+L P / V D)$.

Stocking (lag-1 treatment)

Final model: Ln (Age-1) = random error; $307 \mathrm{df}$, power $>0.99$

\begin{tabular}{cccccc}
\hline Variables & Min & Mean & Max & StdDev & Coefficient \\
\hline Response & 0.00 & 4.94 & 8.78 & 1.59 & - \\
SFI & $<0.01$ & 0.04 & 0.25 & 0.05 & - \\
GDD & 1994 & 3462 & 4468 & 440 & - \\
CDD & 77 & 638 & 1750 & 336 & - \\
SND & 1 & 44 & 439 & 56 & - \\
MAN & 0.00 & 20 & 1110 & 92 & - \\
\hline
\end{tabular}

Aquatic Vegetation Control (lag zero treatment)

Final model: $\operatorname{Ln}\left(\right.$ Age-1) $=$ MAN + error; $\mathrm{r}^{2}=0.1,295 \mathrm{df}$, power $>0.99$

\begin{tabular}{cccccc}
\hline Variables & Min & Mean & Max & StdDev & Coefficient \\
\hline Response & 0.00 & 5.62 & 8.83 & 1.55 & - \\
SFI & $<0.01$ & 0.08 & 1.79 & 0.22 & - \\
GDD & 2524 & 3480 & 4671 & 370 & - \\
CDD & 32 & 593 & 1756 & 336 & - \\
SND & 2 & 37 & 439 & 47 & - \\
MAN $^{*}$ & 0.00 & 0.41 & 1.00 & 0.49 & 0.6 \\
\hline
\end{tabular}

Lake Rehabilitation (lag-1 treatment)

Final model: $\operatorname{Ln}\left(\right.$ Age-1) $=$ SFI + MAN + error; $\mathrm{r}^{2}=0.2,172 \mathrm{df}$, power $>0.99$

\begin{tabular}{cccccc}
\hline Variables & Min & Mean & Max & StdDev & Coefficient \\
\hline Response & 0.00 & 5.53 & 8.95 & 1.71 & - \\
SFI $^{*}$ & $<0.01$ & 0.04 & 0.23 & 0.03 & -9.6 \\
GDD & 2206 & 3372 & 4411 & 422 & - \\
CDD & 91 & 616 & 1827 & 309 & - \\
SND & 1 & 42 & 266 & 44 & - \\
MAN $^{* *}$ & 0.00 & 0.08 & 1.00 & 0.27 & -1.5 \\
\hline
\end{tabular}

Aquatic Vegetation Control (lag-1 treatment)

Final model: Ln (Age-1) = random error; $295 \mathrm{df}$, power $=0.77$

\begin{tabular}{cccccc}
\hline Variables & Min & Mean & Max & StdDev & Coefficient \\
\hline Response & 0.00 & 5.62 & 8.83 & 1.48 & - \\
SFI & $<0.01$ & 0.08 & 1.79 & 0.22 & - \\
GDD & 2524 & 3476 & 4515 & 361 & - \\
CDD & 32 & 587 & 1756 & 343 & - \\
SND & 1 & 38 & 439 & 52 & - \\
MAN & 0.00 & 0.41 & 1.00 & 0.49 & - \\
\hline
\end{tabular}


Lake Rehabilitation (lag-2 treatment)

Final model: $\operatorname{Ln}\left(\right.$ Age-1) $=$ MAN + error; $\mathrm{r}^{2}=0.2,182 \mathrm{df}$, power $>0.99$

\begin{tabular}{cccccc}
\hline Variables & Min & Mean & Max & StdDev & Coefficient \\
\hline Response & 0.00 & 5.41 & 8.95 & 1.88 & - \\
SFI & $<0.01$ & 0.03 & 0.23 & 0.03 & - \\
GDD & 1994 & 3313 & 4411 & 487 & - \\
CDD & 91 & 671 & 1819 & 353 & - \\
SND & 2 & 45 & 312 & 48 & - \\
MAN $^{* *}$ & 0.00 & 0.08 & 1.00 & 0.27 & 1.9 \\
\hline
\end{tabular}

Fish Removal (lag zero treatments)

Final model: Ln (Age-1) = random error; $323 \mathrm{df}$, power $>0.99$

\begin{tabular}{cccccc}
\hline Variables & Min & Mean & Max & StdDev & Coefficient \\
\hline Response & 0.00 & 5.21 & 8.41 & 1.43 & - \\
SFI & $<0.01$ & 0.04 & 0.48 & 0.07 & - \\
GDD & 1994 & 3412 & 4671 & 468 & - \\
CDD & 32 & 595 & 1763 & 352 & - \\
SND & 1 & 40 & 371 & 50 & - \\
MAN & 0.00 & 0.20 & 1.00 & 0.40 & - \\
\hline
\end{tabular}

Lake Water Level Drops (lag-1 treatment)

Final model: $\operatorname{Ln}\left(\right.$ Age-1) $=$ SFI + MAN + error; $\mathrm{r}^{2}=0.1,407 \mathrm{df}$, power $>0.99$

\begin{tabular}{cccccc}
\hline Variables & Min & Mean & Max & StdDev & Coefficient \\
\hline Response & 0.00 & 5.19 & 8.83 & 1.63 & - \\
SFI & $<0.01$ & 0.06 & 1.79 & 0.17 & - \\
GDD & 1994 & 3455 & 4671.04 & 465.26 & - \\
CDD & 32 & 631 & 1827 & 333 & - \\
SND & 1 & 40 & 371 & 48 & - \\
MAN & 0.00 & 20.75 & 457.2 & 65.07 & - \\
\hline
\end{tabular}

Fish Removal (lag-1 treatments)

Final model: $\operatorname{Ln}($ Age-1) $=$ random error; $323 \mathrm{df}$, power $>0.99$

\begin{tabular}{cccccc}
\hline Variables & Min & Mean & Max & StdDev & Coefficient \\
\hline Response & 0.00 & 5.21 & 8.57 & 1.44 & - \\
SFI & $<0.01$ & 0.04 & 0.48 & 0.07 & - \\
GDD & 1994 & 3421 & 4671 & 481 & - \\
CDD & 44 & 608 & 1763 & 356 & - \\
SND & 1 & 41 & 371 & 52 & - \\
MAN & 0.00 & 0.20 & 1.00 & 0.40 & - \\
\hline
\end{tabular}




\begin{tabular}{cccccc}
\hline \multicolumn{7}{c}{\begin{tabular}{l} 
Imposition of a 350 \\
\multicolumn{7}{c}{ mm minimum length limit }
\end{tabular}} \\
& Min & Mean & Max & StdDev & Coefficient \\
\hline Variables & 0.00 & 5.06 & 8.04 & 1.49 & - \\
\hline Response & $<0.01$ & 0.06 & 0.48 & 0.08 & - \\
SFI & 1994 & 3473 & 4671 & 527 & - \\
GDD & 77 & 656 & 1827 & 385 & - \\
CDD & 1 & 43 & 439 & 55 & - \\
SND & 0.00 & 0.38 & 1.00 & 0.48 & 0.7 \\
MAN** & & & & & \\
\hline
\end{tabular}

Imposition of a $375 \mathrm{~mm}$ minimum length limit

Final model: $\operatorname{Ln}($ Adult $)=$ MAN + error; $\mathrm{r}^{2}=0.1,116 \mathrm{df}$, power $=0.9$

\begin{tabular}{cccccc}
\hline Variables & Min & Mean & Max & StdDev & Coefficient \\
\hline Response & 0.00 & 5.50 & 8.00 & 1.38 & - \\
SFI & $<0.01$ & 0.03 & 0.12 & 0.22 & - \\
GDD & 1994 & 3404 & 4175 & 450 & - \\
CDD & 32 & 562 & 1750 & 362 & - \\
SND & 1 & 39 & 371 & 51 & - \\
MAN $^{* *}$ & 0.00 & 0.26 & 1.00 & 0.44 & 0.9 \\
\hline
\end{tabular}

Imposition of a $\mathbf{3 0 0} \mathbf{- 3 7 5} \mathbf{~ m m}$ exclusive slot limit

Final model: $\operatorname{Ln}($ Adult $)=$ MAN + error; $\mathrm{r}^{2}=0.1,116 \mathrm{df}$, power $=0.9$

\begin{tabular}{cccccc}
\hline Variables & Min & Mean & Max & StdDev & Coefficient \\
\hline Response & 0.00 & 4.63 & 7.59 & 1.65 & - \\
SFI & $<0.01$ & 0.03 & 0.08 & 0.02 & - \\
GDD & 2624 & 3350 & 4494 & 326 & - \\
CDD & 80 & 613 & 1520 & 261 & - \\
SND & 1 & 41 & 266 & 41 & - \\
MAN** & 0.00 & 0.31 & 1.00 & 0.46 & 1.6 \\
\hline
\end{tabular}

reduction has also been reported elsewhere [7] [40]. Compared with control years, age-1 largemouth bass declined the year after rehabilitation because the population was dominated by age- 0 largemouth bass present from stocking.

Length limits are one of the most used management tools in the US fisheries sector and are becoming increasingly important [41] [42]. Lakes with persistent large numbers of small fish are strong candidates for regulations. Regulations tend to persist over many years, potentially yielding effects on fish that are more readily detectable compared with other management actions. The results are in agreement with other studies [13] [43] [44], but our study demonstrates a large magnitude of change in the abundance of largemouth bass. Measured effects were usually qualitatively in agreement with the expectations of fisheries managers and the low cost of regulation implementations should keep this practice a 
Table 4. Effects of management practices on age 1 (practices 1 - 3) and adult-size largemouth bass (practices 4 - 6) absolute densities that are statistically significant. Control years correspond to years without any management practice. Treatment years are years when the management practice was observed. Expected means are for log (number of fish sampled per hour of electrofishing after correcting for catchability). Raw CPE are untransformed catch per hour of electrofishing corrected for lake inshore area density. Fish density was estimated using the relationship density $=\left\{\left[(\right.\right.$ fish/hour $\left.) \star 10^{4}\right] /\left(\mathrm{q}^{\star 1550 \star 13)}\right\}$,

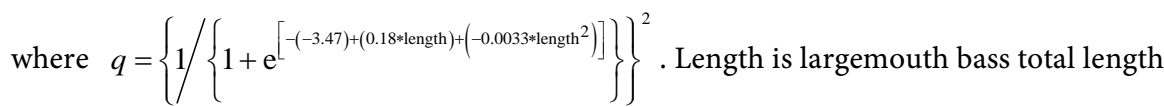
and $\mathrm{N}$ below is sample size.

\begin{tabular}{|c|c|c|c|c|c|c|c|}
\hline \multirow[t]{2}{*}{ Predictor (s) } & \multicolumn{3}{|c|}{ Control Years } & \multicolumn{3}{|c|}{ Treatment Years } & \multirow[b]{2}{*}{$\begin{array}{l}\text { Percent } \\
\text { change } \\
\text { due to } \\
\text { treatment }\end{array}$} \\
\hline & $\begin{array}{l}\text { Expected } \\
\text { mean }\end{array}$ & $\begin{array}{c}\text { Raw CPE } \\
\text { (fish/ha) }\end{array}$ & $\mathrm{N}$ & $\begin{array}{c}\text { Expected } \\
\text { mean }\end{array}$ & $\begin{array}{c}\text { Raw CPE } \\
\text { (fish/ha) }\end{array}$ & $\mathrm{N}$ & \\
\hline $\begin{array}{l}\text { 1. Lag-1 lake } \\
\text { rehabilitation }\end{array}$ & 5.6 & 135 & 162 & 4.2 & 34 & 14 & -75 \\
\hline $\begin{array}{l}\text { 2. Lag-2 lake } \\
\text { rehabilitation }\end{array}$ & 5.3 & 100 & 171 & 7.2 & 665 & 14 & 566 \\
\hline $\begin{array}{l}\text { 3. Lag } 0 \\
\text { aquatic } \\
\text { vegetation } \\
\text { control }\end{array}$ & 5.4 & 110 & 176 & 6.0 & 201 & 122 & 82 \\
\hline $\begin{array}{l}\text { 4. } 350 \mathrm{~mm} \\
\text { minimum } \\
\text { length }\end{array}$ & 4.8 & 61 & 226 & 5.5 & 122 & 136 & 101 \\
\hline $\begin{array}{l}5.375 \mathrm{~mm} \\
\text { minimum } \\
\text { length }\end{array}$ & 5.3 & 100 & 87 & 6.2 & 245 & 31 & 145 \\
\hline $\begin{array}{l}6.300-375 \\
\mathrm{~mm} \text { slot length }\end{array}$ & 4.1 & 30 & 84 & 5.8 & 164 & 37 & 440 \\
\hline
\end{tabular}

preferred choice for managers.

Aquatic vegetation control produced an increase in age- 1 fish during the year of the practice (lag 0 model), possibly due to the sampling method used. Electrofishing catchability has been reported to be an inverse function of vegetative cover [37] [38]. Increased catchability resulting from the reduced aquatic vegetation could have inflated the age- 1 abundance estimates.

Effects from extensive fish removal are commonly detected on fish growth or abundance [45] [46] [47]. The effects of partial, less-extensive fish removals, as examined in this work, are probably weak, if they exist.

Stocking of largemouth bass in Illinois is done with the intention to increase the number of fish or to maintain a pre-existing population size in a lake. No increase in largemouth bass from stocking was evident from this work. Mortality of stocked largemouth bass is probably higher than that of naturally breeding fish [21] [48]. Similarly, as suggested for other species [49] [50], the mortality of stocked largemouth bass is greater when stocking smaller fish. Additionally, establishment of the stocked individuals may increase competition with the natu- 
ral breeding population, potentially defeating the purpose of stocking. Stocking of largemouth bass has occurred in a majority of Illinois lakes, and was more intense after lake rehabilitation. The feasibility of stocking, with costs and benefits from hatchery investments and operations, need to be investigated [51].

This study shows that the water level manipulation technique used in Illinois lakes is an ineffective tool for managing largemouth bass population. Water level manipulations in Illinois are of short duration (few weeks), done during late summer and early fall. Such manipulations are often done to control excessive young fish, which may be more effective when done during spawning periods [11]. A year of low water levels followed by a year of flooding may enhance growth and survival of fish by mimicking floodplain systems [8] [52]. If water level manipulations are to be used for managing largemouth bass abundance, its timing and duration should be reconsidered. Lake rehabilitation involves the most extreme water level manipulation of complete drawdown and subsequent inundation, mimicking river flood pulses [52]. The large effect on a species that has evolved in the original River Mississippi floodplains is, therefore, not surprising.

\subsection{Effects of the Environment}

There was weak evidence for unmanaged environmental predictors affecting largemouth bass abundance. Environmental effects on fish are more often detected in small, shallow lakes or streams [53] [54] [55] [56] [57]. Fish in shallower waters than the lakes in this study tend to be more susceptible to changes in weather, because they are more vulnerable to drought, high temperatures, and winter conditions.

A negative effect of the spring flooding index variable was observed following years with low water levels. High precipitation events are usually preceded or followed by strong winds [58], which may increase water turbidity, causing low nesting success and low egg survival [22] [59] [60].

Temporally and spatially large-scale studies of natural phenomena can be useful for comparisons among systems. In a large-scale study of environmental factors on growth and mortality rates of largemouth bass, [61] found air temperature, latitude, and growing degree days to correlate with fish mortality rates. Temperature has been shown to indirectly affect largemouth bass abundance and growth through trophic and competitive interactions [62].

Snow depth or cooling degree days did not have a detectable effect on largemouth bass abundance. Laboratory experiments suggest that largemouth bass are adapted to cold water [63] [64]. Fish mortality due to low dissolved oxygen caused by ice and snow cover has mostly been reported for small, shallow $(<1 \mathrm{~m})$ eutrophic lakes with rich vegetative cover [65] [66] [67]. Lakes in Illinois, although eutrophic, are usually deeper and at lower latitudes than in the foregoing studies. Winter effects are, thus, expected to be less extreme.

\subsection{Conclusions and Recommendations}

Results for the environmental component should be taken with caution because 
climatic information was used as a surrogate for lake conditions, which may have masked the importance of the natural component. Environmental variables particular to each lake would be more adequate for investigating the effects of the natural component on fish abundance. One could possibly better define the relative importance of the various natural factors when using environmental variables more closely linked to lakes.

Results on management actions indicate that some current practices do have control over fish populations and attempt to optimize such practices are justified. Our results partly support regulations through length limits because such practices produced strong and desirable effects on harvestable fish [42]. Other management practices appeared to affect fish abundance only marginally. Further investigation of these practices might prove valuable. Controlled experiments should be conducted on stocking effects, particularly related to differential mortality between stocked and naturally breeding fish. Similarly, promising management practices such as vegetation controls and water level manipulations (the latter addressing issues related to timing and duration) should be investigated. Controlling the density of vegetation and manipulating water levels may prove to be an inexpensive management tool for manipulating habitat and food supply.

Our results were associated with large unexplained variances, despite the sizable data set available. We believe that it would be difficult to provide more robust results by merely analyzing greater quantities of similar observational data. Because of the wide variety of lake types and angler behavior, fishing regulations might not be universally effective. Current fisheries management involves an ongoing adjustment of practices based on past knowledge and present conditions on individual lakes by individual managers. Long-term testing of feasible management options, based on statistical designs, provides a framework for realizing the goals of fisheries management. Such experimental management techniques [68] [69] [70], whereby control and treatment lakes are used, provide an efficient evaluation process. We believe that the benefits of this process, in which the effects of alternative regulations are compared through the use of different intensities of the same practice during several years ( $>1$ generation of target fish) could outweigh the short-term costs of potential foregone harvest in control lakes.

Although the locations of fish electrofishing sampling stations in Illinois lakes have not changed since 1960, fisheries managers have selected prime areas for fish sampling to maximize the catch. This selection might have yielded estimates of annual fluctuations in fish abundance that were not representative of the entire population in each of the sampled lakes. The selection of sampling locations may have contributed to the infrequency of statistically significant effects of treatments. Fish populations in habitats of marginal quality are likely to be more sensitive to treatment effects, especially those that induce stress. By choosing areas with higher fish abundance, managers may be selectively sampling higher quality habitats, potentially biasing results of management interventions and en- 
vironmental factors on fish. Random selection of sampling stations within a stratum may correct for possible biases due to choosing prime fish habitats. Strata may be defined as low, medium, and high quality habitat for target fish.

Because this work suggests that the management determines fish abundance in Illinois lakes more than do natural factors, the primary responsibility on fisheries agencies to improve fishing opportunities is supported. Although fishing quality is also dependent on biological, economic, and social factors, density of fish of an acceptable size is a key factor. This work demonstrates that management of largemouth bass catch through size limits is strongly related to fish abundance, whereas environmental factors beyond the manager's control have no measurable effect.

\section{References}

[1] Binet, D. (1982) Climatic Changes Related to the Sardinella aurita Fishery of the Ivory Coast and Ghana: A Drought-Overfishing Relationship. Oceanologica Acta, 5, 443-452.

[2] Taylor, D., O’Keefe, P. and Fitzpatrick, C. (1993) A Snow Crab, Chionoecetes opilio (Decapoda, Majidae), Fishery Collapse in Newfoundland. Fishery Bulletin, 92, 412-419.

[3] Baur, R. (1995) Illinois Sport Fishing Survey. Illinois Department of Natural Resources: Report. 56.

[4] Baur, R. and Rogers, R. (1984) 1983 Illinois Sport Fishing Survey. Fisheries, 11, 32.

[5] Knuth, B.A. and McMullin, S.L. (1996) Measuring the Human Dimensions of Recreational Fisheries. In: Murphy, B. and Willis, D., Eds., Fisheries Techniques, 2nd Edition. American Fisheries Society, Bethesda, 651-684.

[6] Noble, R. and Jones, T. (1993) Managing Fisheries with Regulations. In: Kohler, C. and Hubert, W., Eds., Inland Fisheries Management in North America, American Fisheries Society, Bethesda, 383-402.

[7] Hill, H. (1980) Manipulation of Bass-Bluegill Populations by Summer Drawdown. Iowa Conservation Commission, Project No. F-90-R, Des Moines, IA.

[8] Aggus, L. and Elliot, G. (1975) Effects of Cover and Food on Year-Class Strength of Largemouth Bass. In: Stroud, R.H. and Clepper, H., Eds., Black Bass Biology and Management, Sports Fishing Institute, Washington DC, 317-322.

[9] Meals, K. and Miranda, L. (1991) Variability in Abundance of Age-0 Centrarchids among Littoral Habitats of Flood Control Reservoirs in Mississippi. North American Journal of Fisheries Management, 11, 298-304. https://doi.org/10.1577/1548-8675(1991)011<0298:VIAOAC>2.3.CO;2

[10] Martin, D., Mengel, L., Novotny, J. and Walburn, C. (1981) Spring and Summer Water Levels in a Missouri River Reservoir: Effects on Age-0 Fish and Zooplankton. Transactions of the American Fisheries Society, 110, 370-381. https://doi.org/10.1577/1548-8659(1981)110<370:SASWLI >2.0.CO;2

[11] Shields, H. (1957) Experimental Control of Carp Reproduction through Water Drawdowns in Fort Randall Reservoir, South Dakota. Transactions of the American Fisheries Society, 87, 23-33. https://doi.org/10.1577/1548-8659(1957)87[23:ECOCRT]2.0.CO;2

[12] Brousseau, C.S. and Armstrong, E.R. (1987) The Role of Size Limits in Walleye Management. Fisheries, 12, 2-5. 
https://doi.org/10.1577/1548-8446(1987)012<0002:TROSLI >2.0.CO;2

[13] Wilde, G. (1997) Largemouth Bass Fishery Responses to Length Limits. Fisheries, 22, 14-23. https://doi.org/10.1577/1548-8446(1997)022<0014:LBFRTL>2.0.CO;2

[14] Summers, G. (1988) Largemouth Bass Population Changes Following Implementation of a Slot Length Limit. Proceeding of the Annual Conference of the Southeastern Association of Fish and Wildlife Agencies, 42, 209-217.

[15] Kurzawski, K. and Durocher, P. (1993) Effects of a Slot Length Limit on Largemouth Bass in a Newly Opened Texas Reservoir. Proceeding of the Annual Conference of the Southeastern Association of Fish and Wildlife Agencies, 47, 711-719.

[16] Wynne, M., Little, A. and Nelson, K. (1993) Evaluation of a Protected Slot Regulation for Largemouth Bass on Lake Sutton, North Carolina. Proceeding of the Annual Conference of the Southeastern Association of Fish and Wildlife Agencies, 47, 686-694.

[17] Van Horn, S., Chapman, W. and Harris, F. (1983) Results of a 45-cm (18-in) Minimum Size Regulation on Largemouth Bass Populations. Proceeding of the Annual Conference of the Southeastern Association of Fish and Wildlife Agencies, 35, 424-429.

[18] Novinger, G.D. (1987) Evaluation of a 15.0-inch Minimum Length Limit on Largemouth Bass and Spotted Bass Catches at Table Rock Lake, Missouri. North American Journal of Fisheries Management, 7, 260-272. https://doi.org/10.1577/1548-8659(1987)7<260:EOAIML >2.0.CO;2

[19] Austen, D. and Orth, D. (1988) Evaluation of a 305-mm Minimum-Length Limit for Smallmouth Bass in the New River, Virginia and West Virginia. North American Journal of Fisheries Management, 8, 231-239. https://doi.org/10.1577/1548-8675(1988)008<0231:EOAMML>2.3.CO;2

[20] Howick, G., Denoyelles, F., Dewey, S., Mason, L. and Baker, D. (1993) The Feasibility of Stocking Largemouth Bass in 0.04-ha Mesocosms Used for Pesticide Research. Environmental Toxicology and Chemistry, 12, 1883-1893. https://doi.org/10.1002/etc.5620121015

[21] Boxrucker, J. (1986) Evaluation of Supplemental Stocking of Largemouth Bass (Micropterus salmoides) as a Management Tool in Small Impoundments. North American Journal of Fisheries Management, 6, 391-396. https://doi.org/10.1577/1548-8659(1986)6<391:EOSSOL>2.0.CO;2

[22] Kramer, R. and Smith, L. (1962) First-Year Growth of Largemouth Bass, Micropterus salmoides (Lacèpede), and Some Related Ecological Factors. Transactions of the American Fisheries Society, 89, 222-233. https://doi.org/10.1577/1548-8659(1960)89[222:FGOTLB]2.0.CO;2

[23] Miranda, L., Shelton, W. and Bryce, T. (1984) Effects of Water Level Manipulation on Abundance, Mortality, and Growth of Young-of-the-Year Largemouth Bass in West Point Reservoir, Alabama-Georgia. North American Journal of Fisheries Management, 4, 314-320. https://doi.org/10.1577/1548-8659(1984)4<314:EOWLMO>2.0.CO;2

[24] Moss, D. and Scott, D. (1961) Dissolved Oxygen Requirements of Three Species of Fish. Transactions of the American Fisheries Society, 90, 377-393. https://doi.org/10.1577/1548-8659(1961)90[377:DROTSO]2.0.CO;2

[25] Johnson, B. and Martinez, P. (1995) Selecting Harvesting Regulations for Recreational Fisheries: Opportunities for Research/Management Cooperation. Fisheries, 20, 22-29. https://doi.org/10.1577/1548-8446(1995)020<0022:SHRFRF>2.0.CO;2

[26] Austen, D., Sobaski, S., Perea, P., Riedel, R. and Bayley, P. (1996) Compendium of 
143 Illinois Lakes: Bathymetry, Physical and Chemical Features, and Habitats, Vols 1 and 2. Illinois Natural History Survey Technical Report 96/6.

[27] Riedel, R. (1999) Fluctuations in Largemouth Bass (Micropterus salmoides) Abundance According to Anthropogenic and Environmental Factors in Illinois Inland Lakes. PhD Thesis, the University of Illinois, Urbana/Champaign.

[28] Cole, G. (1994) Textbook of Limnology. Waveland Press, Prospect Heights, 412 p.

[29] Rice, J., Breck, J., Bartell, S. and Kitchell, J. (1983) Evaluating the Constraints of Temperature, Activity and Consumption on Growth of Largemouth Bass. Environmental Biology of Fishes, 9, 263-275. https://doi.org/10.1007/BF00692375

[30] McCauley, R. and Kilgour, D. (1990) Effect of Air Temperature on Growth of Largemouth Bass in North America. Transactions of the American Fisheries Society, 119, 276-281. https://doi.org/10.1577/1548-8659(1990)119<0276:EOATOG>2.3.CO;2

[31] Lemons, D. and Crawshaw, L. (1985) Behavioral and Metabolic Adjustments to Low Temperatures in the Largemouth Bass (Micropterus salmoides). Physiological Zoologist, 58, 175-180. https://doi.org/10.1086/physzool.58.2.30158564

[32] Bayley, P. and Austen, D. (1987) Fisheries Analysis System: Data Management and Analysis for Fisheries Management and Research. American Fisheries Society Symposium, 6, 199-205.

[33] Hurley, K., Pope, K. and Willis, D. (1997) Back-Calculated Length-at-Age Estimates from Two Scale Radii. The Prairie Naturalist, 29, 4.

[34] Miller, S. (1984) Age and Growth of Largemouth Bass in Lake Shelbyville, Illinois. Transactions of Illinois Academy of Sciences, 77, 249-260.

[35] Howells, R., Betsill, R. and Prentice, J. (1995) Age Estimation and Length BackCalculation for Known-Age Largemouth Bass. Proceedings of the Annual Conference of the Southeastern Association of Fish and Wildlife Agencies, 49, 167-177.

[36] Fournier, D., Sibert, J., Majkowski, J. and Hampton, J. (1990) Multifan, a Likelihood-Based Method for Estimating Growth Parameters and Age Composition from Multiple Length Frequency Data Sets Illustrated Using Data for Southern Bluefin Tuna (Thunnun maccoyii). Canadian Journal of Fisheries and Aquatic Sciences, 47, 301-317. https://doi.org/10.1139/f90-032

[37] Bayley, P. and Austen, D. (1987) Comparative Analysis of Fish Populations in Illinois Impoundments: Gear Efficiencies and Standards for Condition Factors. Aquatic Biology Technical Report 87/14, Illinois Natural History, Champaign.

[38] Bayley, P. and Austen, D. (2002) Capture Efficiency of a Boat Electrofisher. Transactions of the American Fisheries Society, 131, 435-451. https://doi.org/10.1577/1548-8659(2002)131<0435:CEOABE >2.0.CO;2

[39] Cohen, J. (1988) Statistical Power Analysis for the Behavioral Sciences. LEA, Hillsdale, 567 p.

[40] Pierce, C., Frey, J. and Yawn, H. (1965) An Evaluation of Fishery Management Techniques Utilizing Winter Drawdowns. Proceedings of the Annual Conference of the Southeastern Association of Game and Fish Commissioners, 17, 347-363.

[41] Johnson, M. (1965) Limnology of Ontario Ponds in Relation to Winterkill of Large Mouth Bass. The Progressive Fish-Culturist, 27, 193-198. https://doi.org/10.1577/1548-8640(1965)27[193:LOOPIR]2.0.CO;2

[42] Mather, M., Parrish, D., Stein, R. and Muth, R. (1995) Management Issues and Their Relative Priority within State Fisheries Agencies. Fisheries, 20, 14-21. https://doi.org/10.1577/1548-8446(1995)020<0014:MIATRP>2.0.CO;2

[43] Eder, S. (1984) Effectiveness of an Imposed Slot Length Limit of 12.0-14.9 Inches on 
Largemouth Bass. North American Journal of Fisheries Management, 4, 469-478. https://doi.org/10.1577/1548-8659(1984)4<469:EOAISL >2.0.CO;2

[44] Hoff, M.H. (1995) Comparisons of the Effects of 10-inch, 8-inch, and no Minimum Length Limit on the Smallmouth Bass Population and Fishery in Nebish Lake, Wisconsin. Transactions of the American Fisheries Society, 15, 95-102.

[45] Keith, W.E. (1968) Turbidity Control and Fish Population Renovation on Blue Mountain Lake, Arkansas. Proceedings of the Annual Conference of the Southeas tern Association of Game and Fish Commissioners, 21, 495-505.

[46] Beckman, W. (1941) Further Studies on the Increased Growth Rate of the Rock Bass Ambloplites rupestris Following Reduction of Density in the Population. Transactions of the American Fisheries Society, 70, 143-148. https://doi.org/10.1577/1548-8659(1940)70[143:IGRORB]2.0.CO;2

[47] Jackson, S.W. (1966) Summary of Lake Management Activities on Lakes Eucha and Spavinaw, Oklahoma 1951-1964. Proceedings of the Annual Conference of the Southeastern Association of Game and Fish Commissioners, 19, 315-343.

[48] Filipek, S. and Gibson, M. (1986) Evaluation of Supplemental Stocking of Fingerling Largemouth Bass in Lake Coronado, Arkansas. In: Hall, G. and Van Den Avyle, M., Eds., Reservoir Fisheries Management, American Fisheries Society, Bethesda, 313.

[49] Mitzner, L. (1992) Evaluation of Walleye Fingerling and Fry Stocking in Rathbun Lake, Iowa. North American Journal of Fisheries Management, 12, 321-328. https://doi.org/10.1577/1548-8675(1992)012<0321:EOWFAF>2.3.CO;2

[50] Santucci, V. and Wahl, D. (1993) Factors Influencing Survival and Growth of Stocked Walleye (Stizostedion vitreum) in a Centrarchid-Dominated Impoundment. Canadian Journal of Fisheries and Aquatic Sciences, 50, 1548-1548. https://doi.org/10.1139/f93-176

[51] Epifanio, J. (2000) The Status of Coldwater Fishery Management in the United States: An Overview of State Programs. Fisheries, 25, 13-24. https://doi.org/10.1577/1548-8446(2000)025<0013:TSOCFM>2.0.CO;2

[52] Bayley, P. (1995) Understanding Large River-Floodplain Ecosystems. Bioscience, 45, 153-158. https://doi.org/10.2307/1312554

[53] Larimore, R.W., Childers, W.F. and Heckrotte, C. (1959) Destruction and Reestablishment of Stream Fish and Invertebrates Affected by Drought. Transactions of the American Fisheries Society, 88, 261-285. https://doi.org/10.1577/1548-8659(1959)88[261:DAROSF]2.0.CO;2

[54] Tonn, W.M. and Paszkowski, C.A. (1986) Size-Limited Predation, Winterkill, and Organization of Umbra-Perca Fish Assemblages. Canadian Journal of Fisheries and Aquatic Sciences, 43, 194-202. https://doi.org/10.1139/f86-022

[55] Crivelli, A. and Britton, R. (1987) Life History Adaptations of Gasterosteus aculeatus in a Mediterranean Wetland. Environmental Biology of Fishes, 18, 109-126. https://doi.org/10.1007/BF00002599

[56] Fox, M. and Keast, A. (1990) Effect of Winterkill on Population Structure, Body Size, and Prey Consumption Patterns of Pumpkinseed in Isolated Beaver Ponds. Canadian Journal of Zoology, 68, 2489-2498. https://doi.org/10.1139/z90-348

[57] Fox, M. and Keast, A. (1991) Effect of Overwinter Mortality on Reproductive Life History Characteristics of Pumkinseed (Lepomis gibbosus) Populations. Canadian Journal of Fisheries and Aquatic Sciences, 48, 1792-1799.

https://doi.org/10.1139/f91-211

[58] Coles, J. (1970) Introduction to Meteorology. Wiley, New York, 388 p.

[59] Cross, F. (1967) Handbook of the Fishes of Kansas. Museum of the Natural History 
of the University Kansas, Lawrence, 357 p.

[60] Eiper, A. (1975) Environmental Influences on the Mortality of Bass Embryos and Larvae. In: Stroud, R.H. and Clepper, H., Eds., Black Bass Biology and Management, Sports Fishing Institute, Washington DC, 295-305.

[61] Beamesderfer, R. and North, J. (1995) Growth, Natural Mortality, and Predicted Response to Fishing for Largemouth Bass and Smallmouth Bass Populations in North America. North American Journal of Fisheries Management, 15, 688-704. https://doi.org/10.1577/1548-8675(1995)015<0688:GNMAPR>2.3.CO;2

[62] Olson, M. (1996) Ontogenetic Niche Shifts in Largemouth Bass: Variability and Consequences of First-Year Growth. Ecology, 77, 179-190. https://doi.org/10.2307/2265667

[63] Guest, W. (1982) Survival of Adult Florida and Northern Largemouth Bass Subjected to Cold Temperature Regimes. Proceedings of the Annual Conference of the Southeastern Association of Fish and Wildlife Agencies, 36, 332-339.

[64] Coutant, C. (1975) Responses to Bass to Natural and Artificial Temperature Regimes. In: Stroud, R.H. and Clepper, H., Eds., Black Bass Biology and Management, Sports Fishing Institute, Washington DC, 272-285.

[65] Cooper, G. and Washburn, G. (1949) Relation of Dissolved Oxygen to Winter Mortality of Fish in Michigan Lakes. Transactions of the American Fisheries Society, 76, 23-33. https://doi.org/10.1577/1548-8659(1946)76[23:RODOTW]2.0.CO;2

[66] Casselman, J. and Harvey, H. (1975) Selective Fish Mortality Resulting from Low Winter Oxygen. Verhandlungen zur Internazionale Vereinigung für Limnologie, 19, 2418-2429.

[67] Magnuson, J., Beckel, L., Mills, K. and Brandt, S. (1985) Surviving Winter Hypoxia: Behavioral Adaptations of Fishes in a Northern Wisconsin Winterkill Lake. Environmental Biology of Fishes, 14, 241-250. https://doi.org/10.1007/BF00002627

[68] Walters, C. (1986) Adaptive Management of Renewable Resources. Macmillan, New York, $374 \mathrm{p}$.

[69] Walters, C., Collie, J. and Webb, T. (1988) Experimental Design for Evaluating Transient Responses to Management Disturbances. Canadian Journal of Fisheries and Aquatic Sciences, 45, 530-538. https://doi.org/10.1139/f88-062

[70] McAllister, M. and Peterman, R. (1992) Experimental Design in the Management of Fisheries: A Review. North American Journal of Fisheries Management, 12, 1-18. https://doi.org/10.1577/1548-8675(1992)012<0001:EDITMO>2.3.CO;2 
Submit or recommend next manuscript to SCIRP and we will provide best service for you:

Accepting pre-submission inquiries through Email, Facebook, LinkedIn, Twitter, etc. A wide selection of journals (inclusive of 9 subjects, more than 200 journals)

Providing 24-hour high-quality service

User-friendly online submission system

Fair and swift peer-review system

Efficient typesetting and proofreading procedure

Display of the result of downloads and visits, as well as the number of cited articles Maximum dissemination of your research work

Submit your manuscript at: http://papersubmission.scirp.org/

Or contact nr@scirp.org 